\title{
Evaluation of growth, milk and manure production in Norwegian dairy goats in one highland of Tanzania 30 years after introduction
}

\author{
G. Msalya ${ }^{1 \#}$, V.S. Sonola ${ }^{1,2}$, P. Ngoda ${ }^{1,3}$, G.C. Kifaro ${ }^{1}$ \& L.O. Eik ${ }^{4}$ \\ ${ }^{1}$ Department of Animal, Aquaculture and Range Sciences, Sokoine University of Agriculture (SUA), PO Box 3004, \\ SUA, Morogoro, Tanzania \\ ${ }^{2}$ Livestock Training Agency (LITA), Tengeru Campus, PO Box 3101 Arusha, Tanzania \\ ${ }^{3}$ National Artificial Insemination Centre (NAIC) Arusha, PO Box 557 USA River, Tanzania \\ ${ }^{4}$ Department of Noragric, Norwegian University of Life Sciences (NMBU), PO Box 5003, 1432-Ås, Norway
}

(Received 1 January 2017; Accepted 11 February2017; First published online 20 February 2017)

Copyright resides with the authors in terms of the Creative Commons Attribution 4.0 South African License.

See: http://creativecommons.org/licenses/by/4.0/za

Condition of use: The user may copy, distribute, transmit and adapt the work, but must recognize the authors and the South African Journal of Animal Science.

\begin{abstract}
Dairy goats have been imported into Tanzania since the 1960 s to improve the milk production of Small East African (SEA) goats through crossbreeding. The SEA goats have poor genetic potential for milk. Although crossbreeding programmes started in the early 1980s, most were abandoned or failed for a number of reasons, including lack of performance records, which were important for the design and management of breeding programmes for dairy goats. This study was designed to evaluate growth, lactation, and manure yield in Norwegian Landrace (NL) goats in one rural community of Tanzania. Growth was evaluated in 211 goats by birth weight (BW), weaning weight (WW), weight at six (W6M) and nine months (W9M), and average daily gain (ADG). Lactation performance involved lactation milk yield (LMY), lactation length (LL), and dry off days in 251 does. Twenty four additional goats were confined to determine manure production and chemical composition in a different on-station study. The general linear model (GLM) of Statistical Analysis System (SAS) was used in data analysis. Averages for BW, WW, and adult weight (W9M) were $3.27 \pm 0.04,12.79 \pm 0.09$, and $28.33 \pm 0.19 \mathrm{~kg}$, respectively. Average LMY of 322 litres, LL 214.5 days and dry off days of 84 were obtained. Animals with $\geq 75 \%$ NL genetic make-up produced more milk and showed longer LL and higher ADG than those with 50\%. For example, BW was $3.38 \pm 0.12 \mathrm{~kg}$ in $75 \% \mathrm{NL}$ animals compared with $2.56 \pm 0.12 \mathrm{~kg}$ in $50 \%$, whereas LMY was $324.09 \pm 16.22$ and $248.67 \pm 16.20$, respectively. The amount of manure was $311.8 \mathrm{~g}$ and $218 \mathrm{~g}$ per day for mature and grower goats, respectively. Nitrogen was the major content, comprising $1.98 \%$ of all nutrients in manure. Compared with the early years of introducing NL goats, growth and productivity of milk have increased several fold, indicating that the development of NL goats in Mgeta is positive at the moment.
\end{abstract}

Keywords: Exotic goats, goat kids, Mgeta, productivity, smallholder

\# Corresponding author: msalya@suanet.ac.tz

\section{Introduction}

About 98 per cent of goats in Tanzania belong to the Small East African (SEA breed). Traditionally SEA goats are raised for meat production and are valued by the farmers for traits such as their ability to withstand stresses caused by tropical diseases, high temperatures, drought, and poor feeds. However, they have low genetic potential for meat and milk, poor growth rates, small mature size, and low carcass weights (Chenyambuga et al., 2004). To improve productivity, since the 1960s national development strategies for meat and milk production have emphasized the use of foreign goats such as Boer and Kamorai (meat breeds) and Toggenburg, Saanen, Alpine and Anglo-Nubian (milk breeds) for crossbreeding and upgrading local goats (Das \& Sendalo, 1991). The history of crossbreeding dairy goats in Tanzania dates back to the early 1980s, when exotic dairy goats were imported and reared at missionary centres, church-based organisations, government institutions, non-governmental organisations (NGOs), such as Heifer International $(\mathrm{HI})$ and Farm Africa, and research institutions and universities, including Sokoine University of Agriculture (SUA). For example, Farm Africa, introduced dairy goats in Babati district in 1989 and set up a crossbreeding programme for upgrading local goats with the Toggernburg breed. In addition, HI-Tanzania and World Vision Tanzania introduced Saanen, Anglo-Nubian, and Toggenburg goats in Kongwa district in 2000. In 1983, SUA collaborated with the Agricultural University of Norway (UMB), formerly known as Norwegian University of Life Sciences (NMBU), to initiate a dairy goat crossbreeding programme that utilized Norwegian Landrace 
(NL) goats. The initiative started with 63 two-week-old NL goat kids imported from Norway (Mtenga \& Kifaro, 1992) and evaluated on station performance at SUA (in Morogoro municipality). Then ten pregnant half-bred does (first crosses between SEA and NL goats or 50\% crosses) and ten pure Norwegian bucks were transferred to the rural communities of Mgeta highlands on the south-western side of the Uluguru Mountains in Morogoro region in 1988, where they were followed closely and managed in an open nucleus breeding scheme involving a few villages. Currently, NL dairy goats have become increasingly popular among smallholder farmers and there are approximately 400,000 of these animals countrywide (National Bureau of Statistics, 2012). The approach in almost all projects was the goat credit system or loan-in-kind policy, in which a smallholder farmer was entrusted with a pregnant doe and asked to return the first female kid to the association. That kid was given to the next farmer.

Keeping dairy goats has several advantages for the farmers, such as the availability of enhanced animal protein and improved income from the sales of milk, live animals, and manure (Peacock, 2008). Recently, Chenyambuga et al. (2014) showed that dairy goat enterprises were contributing between 25 and 30 per cent of household incomes in two districts of Tanzania. In Mgeta division, the introduction of dairy goats has contributed to increased household income and reduced vulnerability (Eik et al., 2008). In addition, dairy goats are an alternative source of milk for most rural people who cannot afford to keep dairy cattle. For smallholder farmers, it is often easier to buy a goat than a cow. Moreover, goats require low initial maintenance costs, are relatively inexpensive to keep, and require less fodder and smaller plots (Peacock, 2007). Nutritionally, the consumption of goat milk has reduced malnutrition, especially among poor people in developing countries, and goat milk is tolerated by people with gastro-intestinal disorders (Haenlein, 2004). Compared with cow milk, goat milk is composed of small fat globules, which are easily digested and therefore is considered healthy. Evidence of popularity of goats in Mgeta for example can be shown by the increased number of goats in the division each year. Although the cropping rate is high, a goat census conducted in 2014 showed that 2,000 dairy goats in seven villages of Mgeta division were owned by about 450 farmers (Kifaro et al., 2014, unpublished). There are goats in each of the nearly 30 villages of Mgeta division. From Mgeta, dairy goats have spread throughout the country. The NL is probably the most widely spread breed in Tanzania. Because of increased demand, a pure-breed herd was established in 2008 at Mulbadaw Farm Ltd. in north-central Tanzania (Kifaro et al., 2008).

Among the economically important traits in dairy goats, growth and lactation performance traits are ranked highly (Deribe \& Taye, 2013). Growth traits, such as BW, WW, weight at various ages, ADG, and growth rate (GR) have been emphasized (Berhane \& Eik, 2006; Chanie et al., 2014), as well as lactation performance traits, including lactation milk yield (LMY), LL, and dry off days. In Tanzania and other African countries, these traits are affected by poor management, feed shortage and occurrence of diseases, among other factors. Therefore, goats (dairy and local goats) have low body weights, grow slowly, and are poor producers of milk (Mtenga \& Kifaro, 1992; Berhane \& Eik, 2006). In addition, the economically important traits in goats are influenced by genetic and non-genetic factors, including breed, sex of kids, birth type, age and parity of the dam, as well as season and year of birth. Moreover, there is the challenge of inadequate policies for improvement of dairy goats, because a great deal of attention is given to large animals, especially cattle, which contribute a large share of gross domestic product (GDP) from the livestock sector. In Mgeta, a high cropping rate of goats has led to fast generation turn-overs and has caused inbreeding. Consequently, inbreeding reduces the profitability of dairy goat enterprises in the division and elsewhere (Kifaro et al., 2008).

Manure from goats and other livestock has been used for crop production for many years. The use of manure is one of the most effective ways of improving soil fertility and crop production in Africa. Its production, distribution and application play a vital role in sustaining smallholder arable farming (WattsPadwick, 1983). In addition, manure contributes to the improvement of physical properties of soil, such as soil structure, water-holding capacity, and water infiltration. The improvement of these properties leads to soil and water conservation and consequently increases crop production. In many parts of Tanzania, the majority of farmers use cattle manure. Recently, there has been increasing demand for goat manure, particularly in smallholder farming communities, where many benefits are being realized. In Mgeta, the production of dairy goats has been integrated with the use of manure for gardening, conservation agriculture, and sale of surplus manure for additional income (Kiango, 1996; Kifaro et al., 2012). Elsewhere, Maerere et al. (2001) applied goat manure and found an increase in soil nitrogen $(N)$ and phosphorus $(P)$ for improved root growth, and fresh and dry matter yields of Amaranthus viridis. In a study conducted by Ouda et al. (2006), it was shown that goat manure (the faeces) has a higher content of $\mathrm{N}$ and phosphoric acid than that of cows, and the urine is rich in $\mathrm{N}$ and potassium (K). In Tanzania, little is known about the productivity, composition, and decomposition of goat manure.

Generally, there is a dearth of information about the performance and productivity of dairy goats in the many areas in which introduction of crossbreeding programmes was done. Formal recording systems for 
dairy goats and other livestock species are lacking. Information is based mainly on reports from research projects and some informal reports, which may be unreliable. Recently, Jackson et al. (2014) reported on the performance of Toggenburg goats in Babati and Kongwa districts. For the NL goats, evaluation was done at SUA in 1989 and in Mgeta in 1996 (Kiango, 1989; Kiango, 1996). For the rest of the projects and programmes there is little information about the performance of goats on station or at farmer level. The objective of this study was therefore to carry out an evaluation of NL goats in smallholder farms in Mgeta division. This was important to obtain data that could be used for future recommendations for the design of breeding and management programmes for NL and other dairy goats in Tanzania.

\section{Materials and Methods}

This study was conducted in six villages of Mgeta division, Morogoro region, Tanzania. Mgeta is located at an altitude of 1550 to 1750 metres, about 50 kilometres southwest of Morogoro municipality. The division is mountainous, and has a moderate climate, with an annual range of temperature from 16 to $20^{\circ} \mathrm{C}$, decreasing with altitude, and annual precipitation of about $1400 \mathrm{~mm}$, which supports dairy goat production. This study involved 462 goats (251 does and 211 kids) that were part of 1325 NL goats owned by 61 farmers, who were recruited to participate in a research project, namely innovative dairy goats technologies, between September 2012 and December 2015. Only 462 goats had all the information required for meaningful analyses, while the remaining records were incomplete or incorrect, and therefore were excluded. The farmers were trained in good management practices of dairy goats and data recording at the beginning of the project, and were provided with measuring cylinders, weighing scales, and recording cards. Extension officers obtained data from the farmers' recording cards and transferred it to project assistants at SUA. A simple computer database was designed and used to enter records of animals on four aspects, i) weight of kids from birth to nine months; ii) daily milk yield for does; iii) diseases and treatment and flock dynamics for all categories; and iv) production and use of manure. All animals were managed in a semiintensive system involving daily grazing in the communal fields between 9 am and $4 \mathrm{pm}$, followed by supplementation in the households. Weight was determined by weighing individual goats with a weighing scale (Hanson ${ }^{\mathrm{TM}}$ round spring balance $500 \mathrm{~g}$ accuracy class III model No. 21, H. Enterprises, India). Weighing was done at birth (birth weight (BW)) within 24 hours of birth and then once a month until the age of nine months. Weight records were summarized and presented as i) BW; ii) weaning weight (WW) or weight at age of three months; and post-weaning weights at iii) six months (W6M); and iv) nine months (W9M), respectively. Thereafter, goats were regarded as adults and therefore no more weighing was done. Weight records were further categorized as pre-weaning weight and post-weaning weight from which the pre-weaning and post-weaning growth rates (GR) were computed. GR was estimated using a conventional formula involving weights and the periods by which records were taken:

$\mathrm{GR}=(\mathrm{W} 2-\mathrm{W} 1) /(\mathrm{T} 2-\mathrm{T} 1)$

Where $\mathrm{GR}=$ growth rate

W2 = weight of goat at a desired age

W1 $=$ weight of a goat at a previous age

T2-T1 = time interval (in days) between two specified periods and was presented in grams per day

$(g / d)$.

Lactation was evaluated in three traits, namely lactation length (LL in days), LMY and days dry or dry period. LL was the total number of days from the day of kidding to the dry off date. Recording was done on a day decided by the farmer once a week. This was assumed to be the daily milk yield. To obtain monthly milk yield (MMY) or total LMY, the average of daily yield was multiplied by the number of days in a month (assumed 28 days) or lactation period (days) as illustrated in this formula:

MMY or LMY $=(M Y 1+M Y 2+M Y 3+M Y 4) / 4 \times 28$ or days of lactation

MY1 to MY4 were the chosen milk recording days for four weeks. The dry period (in days) was calculated as the difference in time between the drying off date and the subsequent kidding date.

An additional 24 goats (12 mature and 12 growers) were randomly sampled from the NL dairy goats flock at SUA and confined for 21 days to study the yield and content of manure (goat faeces). Two management systems were used, namely an in-door management system (intensive or total confinement), which was allocated 12 goats (six mature goats or goats aged above 9 months with an average weight of 35 $\mathrm{kg}$ and six growers or goats aged between 6 and 9 months with an average weight of $20 \mathrm{~kg}$ ) and the semiintensive system with the same number and category of goats in which the goats were allowed to graze and browse from 0830 hours to 1300 hours. Data were collected during the last 14 days after allowing them to acclimatize to the experimental conditions or environment in the first seven days. All animals were dewormed with 10\% Albendazole (East Africa Pharmaceuticals, Dar es Salaam) seven days prior to the start of the experiment. The animals were allowed to graze and browse among mature natural pastures and browse trees (basal diet) in reserved plots at SUA. They were also supplied with a locally made supplementary 
concentrate diet comprising maize bran $70 \%$ (energy source), cotton seed cake $25 \%$ (protein), limestone $3 \%$ and bone meal $1.5 \%$ (minerals and vitamins) and common salt $0.5 \%$ (sodium) at $200 \mathrm{~g}$ per animal per day. Each goat was kept in an individual cage $1.2 \mathrm{~m} \times 1.4 \mathrm{~m}$ with a feeder and a watering bucket. Water was provided ad libitum.

The amount of fresh manure was obtained by weighing the sampled manure on each experimental day with a digital weighing scale for each goat in each pen. For animals that were grazing, efforts were made to obtain additional manure (droppings) in the field. From the fresh manure, samples were obtained to evaluate dry matter (DM), organic matter (OM), ash and chemical composition in the laboratory. The samples were first deep-frozen for about 48 hours, followed by oven drying for 24 hours. Analyses followed the laboratory standard procedure according to AOAC (1990). The DM was obtained as percentage of dry samples in the initial fresh weight. The dried samples were placed in a furnace $\left(500{ }^{\circ} \mathrm{C}\right)$ for three hours to obtain ash weight. The OM was estimated as the difference between DM and ash weight. Nitrogen (N) was determined using the Kjeldahl system according to the procedure in Benton (1991). Phosphorus (P) was analysed by the spectrophotometric method using the ICP7AES spectrometer spectroflame Modula according to the manufacturer's instructions (Spectro Analytical Instruments, Kleve, Germany). Potassium (K) was determined by applying a radiometer with an electrode dipped with a reference electrode and a potential. Readings was obtained in millivolts $(\mathrm{mV})$ against a known standard compared with the sample solution.

All data were edited by spreadsheets and subjected to the general linear model (GLM) procedure of Statistical Analysis System (SAS, 2004), involving weight, GR and lactation traits as dependent variables and sex (S) of kids, year $(\mathrm{Y})$ of kidding, season (Se) of kidding, birth type $(\mathrm{T})$ single or twin kids, and parity (P) of the doe as fixed effects. The interaction of fixed factors such as sex and year (SY) and sex and seasons (SSe) were included in the model:

$$
Y_{i j k l m}=\mu+S_{i}+Y_{j}+S e_{k}+T_{1}+P_{m}+(S Y)_{i j}+(S S e)_{i k}+\ldots \ldots \ldots+E_{i j k l m}
$$

Where $Y_{\mathrm{ijklm}}=$ dependent variable (weight, $\mathrm{GR}$, or lactation performance traits)

$\mu=$ general mean, $S_{i}=$ fixed effect due to sex of the goat kids

$Y_{j}=$ fixed effect due to year of kidding

$\mathrm{Se}_{\mathrm{k}}=$ fixed effect due to season of kidding

$T_{1}=$ fixed effect due to type of birth (single or twins)

$P_{m}=$ fixed effect due to parity of the doe

$\mathrm{E}_{\mathrm{ijk} \mathrm{m}}=$ fixed residual effect for each observation (error effect)

In the evaluation of manure, the averages for fresh and dry weight of manure were obtained from raw data, which were collected once daily for the duration of the study. Fresh manure (FM), dry manure (DM), ash, OM, N, P and $\mathrm{K}$ (dependent variables) were estimated and compared among goat classes and management systems (independent variables). For all analyses, $P$-values $<0.05$ were considered significant.

\section{Results}

The results for weights of NL goats managed in smallholder farms in the rural community of Mgeta division in Tanzania are presented in Table 1. The overall averages and ranges (in brackets) of weights in $\mathrm{kg}$ for these parameters were 3.27 (2.56-3.81), 12.79 (11.92-14.14), 20.98 (18.12-22.57) and 28.33 (25.7130.86), respectively. Different factors were shown to affect growth of goats differently. With respect to sex, male goats grow faster $(P<0.01)$ than females in all stages. Concerning the blood level of $\mathrm{NL}$, there was an increase $(P<0.001)$ in weight of goats with increasing blood level. For example, the difference in BW of kids born from $50 \%$ animals $(2.56 \mathrm{~kg})$ and those that were born from $100 \%$ or pure NL animals $(3.81 \mathrm{~kg})$ was 1.27 $\mathrm{kg}$. The difference was much bigger in the later stages of growth. Regarding parity, kids born from does on the high parities (3-5) had larger BW compared with those that were born from does that were on the lower parities (1 and 2). However, there was no significant difference in weight in other stages (WW, W6M and W9M) in relation to parity. A clear difference in weight was observed in all stages for season of birth and type of birth. The authors observed that animals born during the wet season had greater weights than those that were born in the dry season. Single-born kids had greater weights than twin kids. Moreover, there were no significant effects owing to interaction of the factors.

The growth rate was $105.66 \pm 0.03 \mathrm{~g} / \mathrm{d}$ in the pre-weaning phase and $88.80 \pm 0.05 \mathrm{~g} / \mathrm{d}$ in the postweaning phase. The overall growth rate was $92.47 \mathrm{~g} / \mathrm{d}$. There was no significant difference $(P>0.05)$ in growth among the three years in which the data were collected. However, differences were observed when data were separated into the two growth phases. 
Table 1 Mean weights of Norwegian dairy goats $(\mathrm{kg} \pm \mathrm{SE})$ in four stages of development

\begin{tabular}{|c|c|c|c|c|c|}
\hline Factor & Level & Birth weight & Weaning weight & Weight at 6 months & Weight at 9 months \\
\hline \multirow[t]{2}{*}{ Overall } & & $3.27 \pm 0.04(211)$ & $12.79 \pm 0.09(191)$ & $20.98 \pm 0.17(141)$ & $28.33 \pm 0.19(132)$ \\
\hline & 2012 & $3.42 \pm 0.08(82)$ & $12.82 \pm 0.17^{\mathbf{b}}(75)$ & $21.19 \pm 0.36(55)$ & $28.37 \pm 0.40(52)$ \\
\hline \multirow{2}{*}{ Year of birth } & 2013 & $3.24 \pm 0.07(98)$ & $12.72 \pm 0.14^{b}(86)$ & $21.22 \pm 0.29(61)$ & $28.85 \pm 0.34(57)$ \\
\hline & 2014 & $3.40 \pm 0.11(31)$ & $13.84 \pm 0.24^{\mathrm{a}}(30)$ & $20.44 \pm 0.45(25)$ & $27.55 \pm 0.52(23)$ \\
\hline \multirow{4}{*}{ Sex of goats } & Probability & NS & $\star \star \star$ & NS & NS \\
\hline & Females & $3.20 \pm 0.07^{\mathbf{b}}(103)$ & $12.28 \pm 0.15^{b}(94)$ & $19.34 \pm 0.30^{b}(63)$ & $25.65 \pm 0.34^{b}(59)$ \\
\hline & Males & $3.51 \pm 0.07^{\mathrm{a}}(108)$ & $13.97 \pm 0.14^{\mathrm{a}}(97)$ & $22.57 \pm 0.28^{\mathrm{a}}(78)$ & $30.86 \pm 0.31^{a}(73)$ \\
\hline & Probability & ** & $\star * *$ & $\star * \star$ & $\star * *$ \\
\hline \multirow{6}{*}{ Blood level } & $50 \%$ & $2.56 \pm 0.12^{c}(34)$ & $11.92 \pm 0.25^{d}(29)$ & $18.12 \pm 0.52^{b}(19)$ & $25.71 \pm 0.64^{c}(15)$ \\
\hline & $75 \%$ & $3.38 \pm 0.12^{b}(30)$ & $13.01 \pm 0.25^{c}(27)$ & $21.39 \pm 0.57(18)$ & $28.02 \pm 0.66^{\mathbf{b}}(16)$ \\
\hline & $87.5 \%$ & $3.41 \pm 0.09^{b}(55)$ & $13.11 \pm 0.18^{\mathrm{bc}}(54)$ & $21.49 \pm 0.37(41)$ & $28.38 \pm 0.42^{\mathrm{ab}}(38)$ \\
\hline & $93.75 \%$ & $3.58 \pm 0.10^{\mathrm{ab}}(42)$ & $13.38 \pm 0.22^{\mathrm{ab}}(38)$ & $21.85 \pm 0.45(26)$ & $29.05 \pm 0.50^{a}(26)$ \\
\hline & $96.875 \%$ & $3.59 \pm 0.14^{a}(20)$ & $13.20 \pm 0.32^{\mathrm{abc}}(16)$ & $21.49 \pm 0.62(12)$ & $29.08 \pm 0.67^{a}(12)$ \\
\hline & $100 \%$ & $3.81 \pm 0.12^{\mathrm{a}}(30)$ & $14.14 \pm 0.25^{a}(27)$ & $21.40 \pm 0.45(25)$ & $29.28 \pm 0.50^{a}(25)$ \\
\hline \multirow{7}{*}{ Parity of doe } & Probability & $\star \star \star$ & $\star \star \star$ & $\star \star \star$ & $\star *$ \\
\hline & 1 & $3.11 \pm 0.12^{\mathrm{ab}}(33)$ & $12.78 \pm 0.25(30)$ & $20.39 \pm 0.53(21)$ & $27.84 \pm 0.60(20)$ \\
\hline & 2 & $3.21 \pm 0.09^{b}(52)$ & $13.00 \pm 0.19(47)$ & $20.62 \pm 0.37(37)$ & $27.94 \pm 0.44(31)$ \\
\hline & 3 & $3.32 \pm 0.08^{a b}(62)$ & $13.15 \pm 0.17(57)$ & $21.65 \pm 0.38(38)$ & $28.73 \pm 0.43(36)$ \\
\hline & 4 & $3.43 \pm 0.09^{\mathrm{ab}}(43)$ & $13.44 \pm 0.20(39)$ & $21.19 \pm 0.42(29)$ & $28.81 \pm 0.46(29)$ \\
\hline & 5 & $3.70 \pm 0.14^{\mathrm{a}}(21)$ & $13.26 \pm 0.31(18)$ & $20.83 \pm 0.59(16)$ & $28.05 \pm 0.50(16)$ \\
\hline & Probability & * & NS & NS & NS \\
\hline \multirow{3}{*}{$\begin{array}{l}\text { Season of } \\
\text { birth }\end{array}$} & Dry & $3.18 \pm 0.06^{\mathbf{b}}(142)$ & $12.70 \pm 0.14^{b}(131)$ & $20.15 \pm 0.26^{\mathbf{b}}(105)$ & $27.35 \pm 0.29^{b}(99)$ \\
\hline & Wet & $3.53 \pm 0.08^{\mathrm{a}}(69)$ & $13.55 \pm 0.17^{\mathrm{a}}(60)$ & $21.76 \pm 0.38^{\mathrm{a}}(36)$ & $29.16 \pm 0.44^{\mathrm{a}}(33)$ \\
\hline & Probability & $\star \star$ & $\star \star \star$ & $\star \star$ & $\star *$ \\
\hline \multirow{3}{*}{ Type of birth } & Single & $3.61 \pm 0.06^{a}(107)$ & $13.40 \pm 0.41^{\mathrm{a}}(93)$ & $21.61 \pm 0.28^{\mathrm{a}}(65)$ & $28.90 \pm 0.33^{\mathrm{a}}(56)$ \\
\hline & Multiple & $3.10 \pm 0.07^{b}(104)$ & $12.91 \pm 0.15^{\mathbf{b}}(98)$ & $20.30 \pm 0.29^{b}(76)$ & $27.61 \pm 0.32^{b}(76)$ \\
\hline & Probability & $\star \star \star ~$ & * & $\star \star$ & $\star \star \star$ \\
\hline
\end{tabular}

*: significant at $5 \%$

$\star *$ : significant at $1 \%$

***: significant at $0.1 \%$ level

NS: not significant within a factor in a column

With respect to sex of the animals, it was shown that there was higher growth in male than in female animals. Although the pattern was not clear, the authors noted that NL goats with greater blood level $(\geq 75 \%)$ grew faster than those of lower blood level (50\%). For example, the difference in overall growth between $100 \%$ and $50 \%$ animals was $10.41 \mathrm{~g} / \mathrm{d}$. A few exceptions included a lower gain in the $96.875 \%$ animals compared with $93.75 \%$ animals. In terms of parity of the doe, no statistical significance $(P>0.05)$ was observed. Concerning season, it was realized that animals born during the wet season grew faster than those born in the dry season. As for type of birth, single-born animals grew better in the post-weaning phase compared with twin born animals. Also no significant effect was observed following interaction of these effects. Detailed information about growth of NL goats is summarized in Table 2.

An average LMY of 322 litres of milk per animal in 214.5 days LL was obtained (Table 3). The average dry period was 84.5 days. There was a significant difference in LMY between years, type of birth, blood level, parity and season of kidding. Animals reaching $93.75 \%$ of NL blood were shown to be good producers of milk and had the longest LL of 236.1 days compared with the rest of animals. Milk production was highest in third parity does. Parity did not significantly affect the length of the dry period $(P>0.05)$. 
Table 2 Growth of Norwegian dairy goats ( $g / d \pm S E$ ) managed in one rural community of Tanzania

\begin{tabular}{|c|c|c|c|c|}
\hline Factor & & Pre-weaning growth rate & Post-weaning growth rate & Overall growth rate \\
\hline \multirow[t]{2}{*}{ Overall } & & $105.66 \pm 0.03(191)$ & $88.80 \pm 0.05(191)$ & $92.47 \pm 0.02(141)$ \\
\hline & 2012 & $103.84 \pm 1.89^{b}(75)$ & $91.80 \pm 3.39^{\mathrm{a}}(55)$ & $91.75 \pm 1.46(52)$ \\
\hline \multirow{2}{*}{ Year of birth } & 2013 & $104.39 \pm 1.57^{\mathbf{b}}(86)$ & $91.29 \pm 2.74^{\mathrm{a}}(61)$ & $93.76 \pm 1.22(57)$ \\
\hline & 2014 & $115.91 \pm 2.59^{\mathrm{a}}(30)$ & $73.58 \pm 4.14^{b}(25)$ & $88.97 \pm 1.87(23)$ \\
\hline \multirow{4}{*}{ Sex } & Probability & $\star \star$ & * & NS \\
\hline & Females & $110.32 \pm 1.62^{b}(94)$ & $76.31 \pm 2.76^{b}(63)$ & $82.14 \pm 1.23^{b}(59)$ \\
\hline & Males & $115.78 \pm 1.57^{\mathrm{a}}(97)$ & $94.80 \pm 2.56^{a}(78)$ & $100.84 \pm 1.13^{\mathrm{a}}(73)$ \\
\hline & Probability & $\star \star \star$ & $\star \star \star$ & $\star * \star$ \\
\hline \multirow{6}{*}{ Blood level } & $50 \%$ & $103.24 \pm 2.76^{\mathrm{a}}(29)$ & $66.44 \pm 4.87^{\mathrm{a}}(19)$ & $83.50 \pm 2.36^{c}(15)$ \\
\hline & $75 \%$ & $108.20 \pm 2.75^{b}(27)$ & $94.75 \pm 2.56^{b}(18)$ & $91.31 \pm 2.39^{b}(16)$ \\
\hline & $87.5 \%$ & $107.83 \pm 2.02^{b}(54)$ & $90.27 \pm 3.48^{\mathrm{c}}(41)$ & $92.08 \pm 1.53^{\mathrm{ab}}(38)$ \\
\hline & $93.75 \%$ & $109.26 \pm 2.37^{b}(38)$ & $90.20 \pm 4.22^{c}(26)$ & $93.92 \pm 1.79^{\mathrm{a}}(26)$ \\
\hline & $96.875 \%$ & $106.23 \pm 3.48^{c}(16)$ & $89.93 \pm 5.72^{c}(12)$ & $94.24 \pm 2.44^{\mathrm{a}}(12)$ \\
\hline & $100 \%$ & $113.54 \pm 2.78^{d}(27)$ & $81.74 \pm 4.21^{d}(25)$ & $93.91 \pm 1.80^{\mathrm{a}}(25)$ \\
\hline \multirow{7}{*}{ Parity } & Probability & $\star *$ & ** & $\star *$ \\
\hline & 1 & $106.23 \pm 2.79(30)$ & $85.56 \pm 4.92(21)$ & $90.56 \pm 2.15(20)$ \\
\hline & 2 & $107.89 \pm 2.14(47)$ & $84.23 \pm 3.47(37)$ & $90.28 \pm 1.61(31)$ \\
\hline & 3 & $109.24 \pm 1.96(57)$ & $90.79 \pm 3.49(38)$ & $93.66 \pm 1.54(36)$ \\
\hline & 4 & $110.85 \pm 2.24(39)$ & $85.85 \pm 3.89(29)$ & $93.21 \pm 1.67$ (29) \\
\hline & 5 & $106.02 \pm 3.41(18)$ & $81.05 \pm 5.48(16)$ & $89.76 \pm 2.35(16)$ \\
\hline & & NS & NS & NS \\
\hline \multirow{3}{*}{ Season } & Dry & $105.53 \pm 1.48^{\mathrm{b}}(131)$ & $82.70 \pm 2.37^{b}(105)$ & $89.00 \pm 1.04^{b}(99)$ \\
\hline & Wet & $110.56 \pm 1.90^{\mathrm{a}}(60)$ & $88.41 \pm 3.55^{\mathrm{a}}(36)$ & $93.99 \pm 1.59^{\mathrm{a}}(33)$ \\
\hline & Probability & * & * & * \\
\hline \multirow{3}{*}{ Type of birth } & Single & $107.36 \pm 1.55(98)$ & $89.59 \pm 2.68(65)$ & $92.56 \pm 1.21(56)$ \\
\hline & Multiple & $108.73 \pm 1.66(93)$ & $81.52 \pm 2.72(76)$ & $90.44 \pm 1.18(76)$ \\
\hline & Probability & NS & * & NS \\
\hline
\end{tabular}

*significant at $5 \%$

**significant at $1 \%$

$\star * \star$ significant at $0.1 \%$ level

NS: not significant within a factor in a column

Regarding type and season of kidding, it was observed that does kidding in the wet season and those with multiple (twin) kids produced larger amounts of milk than those that kidded in the dry season and those that had single kids. The LL and dry period were not significantly different between the wet and dry seasons and between kidding types (single and multiple kidding). In addition, no statistical significance was observed as a result of interaction of these variables.

Average manure yield in FM and its chemical components are presented in Table 4. The highest yield of FM of $311.8 \mathrm{~g}$ was recorded in the intensive system for mature goats. Mature goats produced more manure than growers in both systems. Likewise, it was confirmed that more manure was obtained in the intensive system than the semi-intensive system. The other parameters (DM, ash and OM) followed a similar trend to FM. The differences were statistically significant at $P<0.001$. Regarding composition, $\mathrm{N}$ was greatest, comprising $1.98 \%$ of total chemicals in manure from growing goats in the semi-intensive system. Composition values for $\mathrm{N}, \mathrm{P}$, and $\mathrm{K}$ are presented in Table 4. No statistical significance was found between classes of goats or systems of production. 
Table 3 Lactation milk yield, lactation length and dry period in Norwegian dairy goats

\begin{tabular}{|c|c|c|c|c|}
\hline Factor & $\mathrm{n}$ & Lactation milk yield (Litres) & Lactation length (days) & Dry period(days) \\
\hline Overall & 251 & $322.24 \pm 7.15$ & $214.5 \pm 0.32$ & $84.47 \pm 16.04$ \\
\hline \multicolumn{5}{|c|}{ Year of Kidding } \\
\hline 2012 & 86 & $347.92 \pm 14.50$ & $221.7 \pm 0.31$ & $104.94 \pm 14.47^{\mathrm{a}}$ \\
\hline 2013 & 122 & $350.33 \pm 10.89$ & $219.6 \pm 0.23$ & $65.79 \pm 14.42^{b}$ \\
\hline \multirow[t]{2}{*}{2014} & 43 & $328.91 \pm 16.26$ & $192.3 \pm 0.35$ & $86.63 \pm 21.74^{\mathrm{ab}}$ \\
\hline & Probability & NS & NS & * \\
\hline \multicolumn{5}{|c|}{ Blood level } \\
\hline $50 \%$ & 49 & $248.67 \pm 16.20^{a}$ & $190.8 \pm 0.35^{a}$ & $80.03 \pm 20.14$ \\
\hline $75 \%$ & 47 & $324.09 \pm 16.22^{a}$ & $200.4 \pm 0.35^{\mathrm{ac}}$ & $107.23 \pm 17.27$ \\
\hline $87.5 \%$ & 45 & $335.73 \pm 16.88^{\mathrm{ab}}$ & $198.6 \pm 0.35^{\mathrm{a}}$ & $96.34 \pm 16.54$ \\
\hline $93.75 \%$ & 37 & $368.01 \pm 18.32^{\mathrm{ab}}$ & $236.1 \pm 0.39^{b}$ & $97.40 \pm 18.26$ \\
\hline $96.875 \%$ & 40 & $359.90 \pm 17.28^{\mathrm{ab}}$ & $213.9 \pm 0.37^{\mathbf{b c}}$ & $63.22 \pm 17.39$ \\
\hline \multirow[t]{2}{*}{$100 \%$} & 33 & $417.93 \pm 19.49^{b}$ & $227.7 \pm 0.42^{\mathrm{bc}}$ & $70.50 \pm 19.50$ \\
\hline & Probability & $\star \star \star$ & * & NS \\
\hline \multicolumn{5}{|l|}{ Parity } \\
\hline 1 & 57 & $332.25 \pm 15.82^{\mathrm{ab}}$ & $206.7 \pm 0.34$ & $107.28 \pm 15.70$ \\
\hline 2 & 64 & $351.41 \pm 14.36^{\mathrm{bcd}}$ & $213.9 \pm 0.31$ & $75.47 \pm 13.47$ \\
\hline 3 & 60 & $376.63 \pm 14.52^{d}$ & $219.0 \pm 0.31$ & $63.15 \pm 13.14$ \\
\hline 4 & 46 & $350.91 \pm 16.25^{a b c}$ & $219.9 \pm 0.35$ & $83.12 \pm 17.05$ \\
\hline \multirow[t]{2}{*}{5} & 24 & $300.74 \pm 21.87^{a}$ & $199.8 \pm 0.47$ & $99.92 \pm 13.17$ \\
\hline & Probability & * & NS & NS \\
\hline \multicolumn{5}{|c|}{$\begin{array}{l}\text { Season of } \\
\text { kidding }\end{array}$} \\
\hline Dry & 198 & $306.35 \pm 8.77^{a}$ & $209.7 \pm 0.18$ & $75.53 \pm 11.37$ \\
\hline \multirow[t]{2}{*}{ Wet } & 53 & $378.45 \pm 15.26^{b}$ & $212.7 \pm 0.32$ & $96.04 \pm 18.44$ \\
\hline & Probability & $\star \star \star$ & NS & NS \\
\hline \multicolumn{5}{|c|}{ Type of kidding } \\
\hline Single & 120 & $319.21 \pm 10.86^{a}$ & $213.9 \pm 0.23$ & $84.48 \pm 13.72$ \\
\hline \multirow[t]{2}{*}{ Multiple } & 131 & $365.57 \pm 11.37^{\mathbf{b}}$ & $208.5 \pm 0.24$ & $87.10 \pm 12.94$ \\
\hline & Probability & $\star \star \star$ & NS & NS \\
\hline
\end{tabular}

*significant at 5\%

** significant at $1 \%$

***significant at $0.1 \%$ level

NS: not significant within a factor in a column

\section{Discussion}

Previous studies have shown that keeping dairy goats improves nutrition, increases income, and reduces vulnerability (Eik et al., 1985) in the smallholder households. However, there has been little information about the performance and productivity of dairy goats in Tanzania. The authors carried out this study to investigate the performance of selected traits of growth (weight and GR) and lactation (MY, LL and dry periods) on farm in the rural community of Mgeta, and manure production in an on-station study to inform the development and productivity of NL goats after 30 years of introduction. On-farm evaluation provides information on location and breeds specific performance and breed improvement options that are appropriate to target system of production or management. In Tanzania, formal recording systems for dairy goats and other livestock species are lacking. 
The BW values in the present study were considered higher than those reported for NL goats on station and on farm in Tanzania and elsewhere, which ranged from 2.0 to $2.6 \mathrm{Kg}$ (Hamad, 2001; Kiango,

Table 4 Yield and composition of manure in Norwegian dairy goats in Tanzania

\begin{tabular}{|c|c|c|c|c|c|c|c|c|}
\hline \multirow{2}{*}{ Class } & \multirow{2}{*}{$\begin{array}{l}\text { Management } \\
\text { system }\end{array}$} & \multicolumn{4}{|c|}{ Yield of manure (in grams) } & \multicolumn{3}{|c|}{ Percentage composition of NPK } \\
\hline & & FM & DM & Ash & OM & $\mathrm{N}(\%)$ & $\mathrm{P}(\%)$ & $\mathrm{K}(\%)$ \\
\hline Overall & & $235.85 \pm 3.05$ & $216.38 \pm 2.87$ & $25.82 \pm 1.12$ & $190.55 \pm 2.79$ & $1.85 \pm 0.05$ & $1.16 \pm 0.05$ & $1.36 \pm 0.10$ \\
\hline \multirow{2}{*}{ Mature } & Intensive & $311.8 \pm 4.31^{\mathrm{a}}$ & $285.4 \pm 4.06^{\mathrm{a}}$ & $32.6 \pm 1.59^{\mathrm{a}}$ & $252.8 \pm 3.96^{\mathrm{a}}$ & $1.81 \pm 0.07$ & $1.09 \pm 0.06$ & $1.25 \pm 0.09$ \\
\hline & Semi-intensive & $255.8 \pm 4.31^{b}$ & $234.6 \pm 4.06^{b}$ & $27.5 \pm 1.12^{b}$ & $207.0 \pm 3.96^{\mathbf{b}}$ & $1.85 \pm 0.06$ & $1.03 \pm 0.07$ & $1.48 \pm 0.07$ \\
\hline \multirow{4}{*}{ Growers } & & *** & *** & *** & $* * *$ & NS & NS & NS \\
\hline & Intensive & $218.0 \pm 4.31^{\mathrm{c}}$ & $200.9 \pm 4.06^{c}$ & $25.1 \pm 1.12^{\mathrm{c}}$ & $175.8 \pm 3.96^{\mathrm{c}}$ & $1.75 \pm 0.05$ & $1.35 \pm 0.06$ & $1.40 \pm 0.07$ \\
\hline & Semi-intensive & $157.9 \pm 4.31^{d}$ & $144.7 \pm 4.06^{\mathrm{d}}$ & $18.1 \pm 1.51^{\mathrm{d}}$ & $126.7 \pm 3.96^{d}$ & $1.98 \pm 0.08$ & $1.20 \pm 0.07$ & $1.31 \pm 0.08$ \\
\hline & & *** & *** & *** & $* \star *$ & NS & NS & NS \\
\hline
\end{tabular}

FM: fresh manure; DM: dry manure; OM: organic matter; N: nitrogen; P: phosphorus; K: potassium

$\star \star \star$ : significant at $0.1 \%$ level

NS: not significant

1996; Eik et al., 2008; Petros et al., 2013). The BW in NL goats in the same area of Tanzania increased by a factor of 1.2 between 5 and 10 years. The improved performance for NL goats may be the result of improved management practices at the present time (2012 to 2014) compared with past years. Good management has been developed gradually through continuous contact between the farmers, SUA staff, and extension workers, as well as by training the farmers for over 25 years. The training included introductory courses on goat husbandry and health, feeding and pasture, breeding, economics, milk by-products, and advanced animal health (Mtenga \& Kifaro, 1992; Kifaro et al., 2012). Seemingly, NL goats are lighter in terms of BW than the Saanen, Toggenburg and Alpine breeds, in which values of 3.56, 3.5 and $4.11 \mathrm{~kg}$, respectively, have been reported (Pavic et al., 1988; Majid et al., 1993). In the neighbouring country of Kenya, weights of Toggernburg goats at age 60 days were reported to reach $13 \mathrm{~kg}$ (Ruvuna et al., 1988), which is a heavier weight than weights of all groups of NL goats at weaning age in the present study. According to these authors, the ADG in Toggernburg in the same study was $230 \mathrm{~g} / \mathrm{d}$. Factors affecting weights and growth in the present study were reported by Ruvuna et al. (1988) in other breeds.

Milk production in goats is affected by several factors, including breed and genetic constitution of the animal (Damian et al., 2008), udder morphology (Moatsou et al. 2004), parity (Ahuya et al., 2009), feeding and nutrition (Dønnem et al., 2011), litter size (Ahuya et al., 2009), and kidding period (Crepaldi et al., 1999). In the present study, non-genetic factors, such as year of kidding, season of kidding, parity of dam, blood level and type of birth, were considered in the analyses of lactation performance of NL goats. The current analyses and results are evidence that there is greater development in milk production in NL goats in the study area. In 2012, the authors reported an average production of 1.4 litres of milk per goat per day, average sales of up to 2 litres of milk per household per day, and an average consumption of 1.2 litres of milk per household per day (Kifaro et al., 2012). The average milk yield for these goats in Norway is 1.6 litres of milk per day or $600 \mathrm{~kg}$ per lactation. Earlier studies by Kiango (1996) and Hamad (2001) suggested lower LMY values per lactation than in the present study in the same goats (176 and 126 litres, respectively). Elsewhere in African local goats or crossbred, LMY was lower than those reported in this study (Berhane \& Eik, 2006). Although it is understood that other goats produce above 450 litres per lactation (Guney et al., 2006) or more than what presented for NL goats in the present study, performance and development in Mgeta are positive and encouraging. Regarding the factors that influence lactation performance, there are several explanations for them. Parity can influence LMY because of the older age of the doe and is a factor of a greater volume of udder in does in later parities and the proportion of mammary alveoli, which do not undergo complete regression after previous lactations as shown by Muller (2005). Variations in LMY between years or season can be explained by the availability of adequate forages and nutrition management in good years (with good rainfall and enough feeds), as well as in the wet season. There is scarcity of feed for animals in the dry season and in some years.

Goat manure is now being used in many parts of East Africa as an excellent fertilizer and has good potential for increasing crop productivity. In addition, it has commercial value through which farmers can sell goat manure and earn additional income (Eik et al., 2008). In the authors' recent studies in the same area, 
they reported that about $82 \%$ of the farmers enrolled in the dairy goat project were using goat manure in gardens (Kifaro et al., 2012). There are prospects of combining biogas from dairy goats with the year-round irrigated horticulture production (Grimsby et al., 2016). In a study conducted in South Africa, it was reported that goat manure improved the effectiveness of $P$ fertilizer, and its co-application increased maize growth (Gichangi et al., 2010). As expected, the authors have shown that better manure yield is obtained in the intensive system than in the semi-intensive system, because there is loss of manure in the field during grazing. Therefore, the intensive system is important if manure from goats has to be retained. Unsurprisingly, mature goats produced more manure than growing goats. This is because of the differences in feed intake and metabolic activities between the two classes. Regarding the chemical composition, manure from dairy goats contained adequate amounts of nutrients, especially higher contents of $\mathrm{N}$ and $\mathrm{P}$ for optimal growth of plants, as suggested by Gichangi et al. (2010). The major constraints when considering goat manure in developing countries may include collection challenges, determining the right levels of application, and identifying soils that lack the nutrients that goat manure can offer.

Although they are small in number (for example only $2 \%$ of over 15 million goats in Tanzania), the potential of dairy goats for the livestock industry is based on the reasons that i) they can perfectly replace dairy cows in places where they cannot be raised for various reasons, in particular in urban, peri-urban, steep mountainous areas and poor rural communities to supply milk, meat, skin and manure; ii) bucks (male dairy goats) can be used meaningfully for crossbreeding with local goats to increase MY, improve GR and improve meat production potential; iii) they can be ideal animals for research in the fields of nutrition and dairy science because of their small size; and iv) they are more efficient than cows at converting feed to milk based on amount of milk produced as a ratio of feed consumed or based on bodyweight.

\section{Conclusions}

The NL goats were imported to Tanzania in 1983 and were transferred to Mgeta in 1988. The authors have shown that the performances of these goats for BW, WW, weight at different stages of growth, MY, manure yield and content of manure were within the recommended rates for NL and other dairy goats elsewhere. The overall values obtained for BW, WW, W6M and W9M (all animals) were $3.27 \pm 0.04 \mathrm{~kg}$, $12.79 \pm 0.09 \mathrm{~kg}, 20.98 \pm 0.17 \mathrm{~kg}$ and $28.33 \pm 0.19 \mathrm{~kg}$, respectively. With regard to growth (ADG), the overall values were $105.66 \pm 0.03 \mathrm{~g} / \mathrm{d}$ and $88.80 \pm 0.05 \mathrm{~g} / \mathrm{d}$ during the pre-weaning and post-weaning periods. Concerning LMY, the authors showed that their goats in Mgeta could produce on average $322.24 \pm 7.15$ litres of milk in $214.5 \pm 0.32$ lactation days. Furthermore, better performance for growth, MY and lactation is associated with the increased blood level of NL goats. For example, the difference in BW between $50 \%$ animals and $100 \%$ was $1.27 \mathrm{~kg}(2.56 \mathrm{~kg}$ for $50 \%$ kids and $3.81 \mathrm{~kg}$ for $100 \%)$. They also noted that a reasonable amount of good quality goat manure can be collected and utilized to fertilize gardens and homestead farms where dairy goat farming is practised. However, they emphasize that animals with greater NL blood level need more investment in management, particularly feeding, housing, and disease control for more productivity.

\section{Acknowledgements}

The authors acknowledge the generous funding of the Royal Government of Norway for the Innovative dairy goat technologies project through the Programme for Enhancing Pro-poor Innovation in Natural Resources and Agricultural Value Chains (EPINAV) Grant No. 1.1/06. The project was implemented at SUA from 2011 to 2016. They thank the farmers for their willingness to participate in the project and the extension officers (W Shekilango, J Shekilango and $\mathrm{R}$ Paulo) for following up the farmers and for collecting the data.

\section{Authors' Contributions}

GM, VSS, GCK and PN designed the experiments. GM, VSS and PN carried out the analysis and drafted the manuscript. VSS did the statistical analyses. GM, GCK and LOE structured scientific content. All authors provided editorial suggestions and revisions, and read and approved the final draft.

\section{Conflict of Interest Declaration}

The authors declare that they have no conflict of interest for this article.

\section{References}

Association of Official Analytical Chemists (AOAC), 1990. Official methods of analysis. 17th edition, Arlington, VA. pp 1298.

Ahuya, C.O., Ojango, J.M.K., Mosi, R.O., Peacock, C.P. \& Okeyo A.M., 2009. Performance of Toggenburg dairy goats in smallholder production systems of the eastern highlands of Kenya. Small Rumin. Res. 83, 7-13.

Benton, J.J., 1991. Kjeldahl method for nitrogen determination. Micro-Macro Publishing, Athens. pp 4-8.

Berhane, G. \& Eik, L.O., 2006. Effect of vetch (Vicia sativa) hay supplementation to Begait and Abergelle goats in Northern Ethiopia II. Reproduction and growth rate. Small Rumin. Res. 64, 233-240. 
Chanie, D., Mekuriaw Z. \& Taye, M., 2014. Evaluation of pre-weaning growth performances and survival rate of Western Highland goats under traditional management in Amhara region, Ethiopia. Livestock Research for Rural Development, 26, 145. Retrieved 30 May 2016, from http://www.Irrd.org/lrrd26/8/chan26145.htm.

Chenyambuga, S.W., Hanotte, O., Watts, P.C., Kemp, S.J., Kifaro, G.C., Gwakisa, P.S., Petersen, P.H. \& Rege, J.E.O., 2004. Genetic characterization of indigenous goats of south Saharan Africa using microsatellite DNA markers. Asian Austral. J. Anim. Sci. 17, 445-452.

Chenyambuga, S.W., Jackson, M., Ndemanisho, E.E. \& Komwihangilo, D.M., 2014. Profitability and contribution of smallscale dairy goat production to income of smallholder farmers in Babati and Kongwa districts, Tanzania. Livest. Res. Rural Dev. 26, 27. Retrieved 22 May 2016, from http://www.Irrd.org//rrd26/2/chen26027.html.

Crepaldi, P., Corti, M. \& Cicogna, M., 1999. Factors affecting milk production and prolificacy of Alpine goats in Lombardy (Italy). Small Rumin. Res. 32, 83-88.

Damian, J.P., Sacchi, I., Reginensi, S., De Lima, D. \& Bermudez, J., 2008. Cheese yield casein fraction and major components of milk of Saanen and Anglo-Nubian dairy goats. Arg. Bras. Med. Vet. Zootec. 60, 1564-1569.

Das, S.M. \& Sendalo, D.S.C., 1991. Small ruminant research highlights in Tanzania. Ministry of Agriculture and Livestock Development. Dar es Salaam. pp. 40.

Deribe, B. \& Taye, M., 2013. Evaluation of growth performance of Abergelle goats under traditional management systems in Sekota district, Ethiopia. Pakistan J. Biol. Sci. 16, 692-696

Dønnem, I., Randby, Å.T. \& Eknæs, M., 2011. Effect of grass silage harvesting time and level of concentrate supplementation on goat milk quality. Anim. Feed Sci. Technol. 163, 118-129.

Eik, L.O., Mtenga, L.A. \& Olsen, O.H.E., 1985. Preliminary results on some economic traits in Norwegian and Tanzanian x Saanen goats. In: Tanzania Society of Animal Production Conference series. 12, 129-142.

Eik, L.O., Kifaro, G.C., Kiango, S.M., Nordhagen, Ø.M., Safari, J. \& Mtenga, L.A., 2008. Productivity of goats and their contribution to household food security in high potential areas of East Africa: A case of Mgeta, Tanzania. Afr J. Food Agric. Nutr. Dev. 8, 278-290.

Gichangi, E.M., Mnkeni, P.N.S. \& Brookes, P.C., 2010. Goat manure application improves phosphate fertilizer effectiveness through enhanced biological cycling of phosphorus. Soil Sci. Plant Nutr 56, 853-860. DOI: 10.1111/j.1747-0765.2010.00515.x

Guney, O., Torun, O., Ozuyanik, O. \& Darcan, N., 2006. Milk production, reproductive and growth performances of Damascus goats under northern Cyprus conditions. Small Rumin. Res. 65, 176-179.

Grimsby, L.K., Gulbrandsen, L., Eik, L.O, Msalya, G. \& Kifaro, G.C., 2016. The prospect of biogas among small-holder dairy goat farmers in the Uluguru Mountains, Tanzania. Afr J. Food Agric. Nutr. Dev. 16, 10727-10741. DOI: 10.18697/ajfand.73.15650.

Haenlein, G.F., 2004. Goat milk in human nutrition. Small Rumin. Res. 51, 155-163.

Hamad, A.H., 2001. An evaluation of performance of crossbred dairy goats at Magadu Dairy farm. MSc dissertation, Sokoine University of Agriculture, Morogoro, Tanzania. pp 136.

Jackson, M., Chenyambuga, S.W., Ndemanisho, E.E. \& Komwihangilo, D.M., 2014. Production performance of Toggenburg dairy goats in semi-arid and sub-humid areas of Tanzania. Livest. Res. Rural Dev. 26, 30. Retrieved 22 May 2016, from http://www.Irrd.org//rrd26/2/jack26030.htm

Kiango, S.M., 1989. Some factors influencing performance of dairy goats at Magadu Farm. BSc special project, Sokoine University of Agriculture, Morogoro, Tanzania. pp 67.

Kiango, S.M., 1996. Studies on factors affecting performance of dairy goats and socio- economic aspects of dairy goat production in Tchenzema and Dareda wards in Tanzania. MSc dissertation, Sokoine University of Agriculture, Morogoro, Tanzania. pp 184.

Kifaro, G.C., Msalya, G., Nziku, Z., Ndemanisho, E.E., Kimbita, E.N., Mushi, D.E., Max, R.A. \& Mtenga, L.A., 2012. Status of Norwegian dairy goats in two districts of Morogoro region at the start of an up-scaling project. Oral presentation, 1st Annual Conference of the EPINAV Programme, Morogoro, Tanzania, 18-19 December 2012.

Kifaro, G.C., Eik, L.O., Mtenga, L.A., Mushi, D., Safari, E.J., Kassuku, A.A., Kimbita, E.N., Maeda-Machang'u, A.D., Kanuya, N.L., Muhikambele, V.R.M., Ndemanisho, E. \& Ulvund, M.J., 2008. The potential use of artificial insemination in sustainable breeding of dairy goats in developing countries: A case study of Norwegian dairy goats' in Tanzania. Tanzania J. Agric. Sci. 8, 19-24.

Maerere, A.P., Kimbi, G.C. \& Nonga, D.L.M., 2001. Comparative effectiveness of animal manures on soil chemical properties, yield, and root growth of Amaranthus. Afr J. Sci. Technol. 1, 14-21.

Majid, A.M., Cartwright, T.C., Yazman, J.A. \& Fitz-Hugh, H.A.J., 1993. Performance of live breeds of dairy goats in Southern United States 1. Reproductive traits and maturing pattern. J. World Rev. Anim. Prod. 28, 15-23.

Moatsou, G., Samolada, M., Panagiotou, P. \& Anifantakis, E., 2004. Casein fraction of bulk milks from different caprine breeds. Food Chem. 87, 75-81.

Mtenga, L.A. \& Kifaro, G.C., 1992. Dairy goat research and extension at Sokoine University of Agriculture (lowlands) and Mgeta (highlands) areas of Tanzania. In: Kategile, J.A., Mubi, S. (eds.), Future of livestock industries in East and Southern Africa, Proceedings of a Workshop, Kadoma Ranch Hotel, Zimbabwe, 20-23 July, 1992. International Livestock Centre for Africa (ILCA), Addis Ababa, Ethiopia. pp 227.

Muller, C.J.C., 2005. Genetic parameter estimation and breeding plans for the South African dairy goat herd. PhD dissertation submitted to the Department of Animal Sciences, Faculty of Agricultural and Forestry Sciences, University of Stellenbosch. pp 123.

National Bureau of Statistics, 2012. National sample census of agriculture 2007/08. Large scale farms volume IV. Ministry of Agriculture, F. S. a. C., Ministry of Livestock Development and Fisheries, Ministry of Water and Irrigation, Ministry of Agriculture, Livestock and Environment, Zanzibar, Prime Minister's Office, Regional 
Administration and Local Governments, Ministry of Industries, Trade and Marketing, National Bureau of Statistics, and Office of the Chief Government Statistician, Zanzibar. Dar es Salaam, National Bureau of Statistics.

Ouda, J.O., Modi, A.T. \& Nsahlai, I.V., 2006. Nutrient flow and manure quality in different diets fed to ruminant. In: Tenywa, M.M., Semalulu, O., Kasenge, V., Taulya, G., Musinguzi, P. (eds.), The 23rd Soil Science Society of East Africa (SSSEA) Conference Proceedings. pp 23.

Pavic, V., Mioc, B., Crnojevic, Z. \& Kitonic, A., 1988. Some reproductive traits of goats in intensive milk production system. Agriculturae Conspectus Scientificus 53, 87-94.

Peacock, C., 2007. The goats model. A proven approach to reducing poverty among smallholder farmers in Africa by developing profitable goat enterprises and sustainable support services. Farm-Africa, Working Papers 9, 4-15.

Peacock. C., 2008. Dairy goat development in East Africa: A replicable model for smallholders? Small Rumin. Res. 77 , 225-238.

Petros, A., Kebede, A. \& Wolde, A., 2013. Prevalence and economic significance of bovine fascioliosis in Nekemt Municipal Abattoir. J. Med. Anim. Health 5, 202-205.

Ruvuna, F., Cartwright, T.C., Blackburn, H., Okeyo, M. \& Chema, S., 1988. Gestation length, birth weight and growth rates of pure-bred indigenous goats and their crosses in Kenya. J. Agric. Sci. 111, 363-368.

SAS, 2004. Statistical Analytical System. User guide for personal computers, statistical programme- Windows Version 9.2, SAS Institute Inc. Cary, NC, USA. pp 232.

Watts-Padwick, G., 1983. Fifty years' experimental agriculture. II. The maintenance of soil fertility in tropical Africa. A Review. Exp. Agr. 19, 293-310. DOI:.

Zervas, G. \& Tsiplakou, E., 2013. Goat milk. In Park, Y.W., Haenlein, G.F.W. (eds). Milk and dairy products in human nutrition: production, composition and health. London, Wiley-Blackwell. pp 498-518. 